Research Article

\title{
New Record of Marine Parasitic Isopods (Family, Corallinidae) from South Andaman, Andaman Islands, India
}

\author{
Pathan Anil *, Tarun Das, Kadeparambil Arjunan Jayaraj \\ Department of Ocean Studies and Marine Biology, School of Life Sciences, Pondicherry University, Port Blair \\ Campus, Andaman Islands 744112, India
}

Article history:

Submission May 2018

Revised September 2018

Accepted September 2018

*Corresponding author:

E-mail: anil.federer070@gmail.com

\begin{abstract}
Parasitic isopods are causing problems to the worldwide fishery resources. The studies on parasitic isopods are very scanty in Andaman Islands. So here we provided information on the distribution of two species of parasitic isopods of fishes from Junghlighat fish landing center of South Andaman. The two marine parasitic isopods species are Argathona rhinoceros (Bleeker 1857) and Argathon amacronema (Bleeker 1857). They found to infest the host marine fishes Epinephelus coioides (Hamilton 1822) and Epinephelus tauvina (Forsskal 1775) respectively. These two species were collected from the nostril cavity of the individual host fishes. The morphological characteristics of two specimens are described in detail. Prevalence of corallinids provides additional information to update the check list of isopods from Andaman and Nicobar Islands.
\end{abstract}

Keywords: Corallinidae, Parasitic isopods, Argathona spp. Epinephelus spp. South Andaman, India

\section{Introduction}

One of the major cosmopolitan phenomenon in almost all the habitats is the parasitic infestation, mainly in the aquatic biota [1]. Owing to the increasing importance of marine aquaculture concerns on fish health through the pollution and parasitic causing diseases, in the 21 centuries, the Marine fish parasitology is a hastily developing field of aquatic science [2]. The systematic study on Marine fish parasitology and their diseases are comparatively new [3]. Parasites are invertebrate and unique group of organisms they adapt to parasitic way of life. These organisms can accommodate with different species of animals both temporarily or permanently [4]. They are blood suckers and protandric hermaphrodites. Usually they are living in the gill chambers, in the mouth of the fishes or on the skin [5]. Among these parasites some are free-living and they can become opportunistic parasites (Family, Corallanidae) But others require hosts for their continued existence and reproduction, and these parasites are referred to as obligate parasites [6]. Among the crustacean ecto parasites of both marine and fresh water fishes, parasitic isopods are the dominant groups. Till date, about 450 species are recorded as a parasite which are varying from 0.5 to $440 \mathrm{~m}$ in length [5, 7]. Bunkley-Williams et al. (2006) identify the largest species on the earth occurs of Puerto Rico. Because of their serious damage to global fishery resources, these marine parasitic isopods are receiving more considerable scientific interest [9].

The parasitic works in Andaman Islands were poorly studied and very few reports were noted and scarce literature is available regarding these parasitic isopods [10]. Among the isopod crustaceans, the family Corallanidae is of special interest because their hosts are fishes of commercial importance [7]. The Corallanidae (crustacea, isopoda, flabellifera) is a small family compiled of six genera (Tachaea, Argathona, Excorllana, Alcirona, Corallana and Lanocira) and contain 67 species. The members of the family were confined mainly to tropical and sub-tropical shallow water marine habitats and also present in fresh water and brackish water habitats [11]. Species belongs to

\section{How to cite:}

Anil P, Das T, Jayaraj KA (2018) New Record of Marine Parasitic Isopods (Family, Corallinidae) from South Andaman, Andaman Islands, India. Journal of Tropical Life Science 8 (3): 295 - 302. doi: 10.11594/jtls.08.03.12 


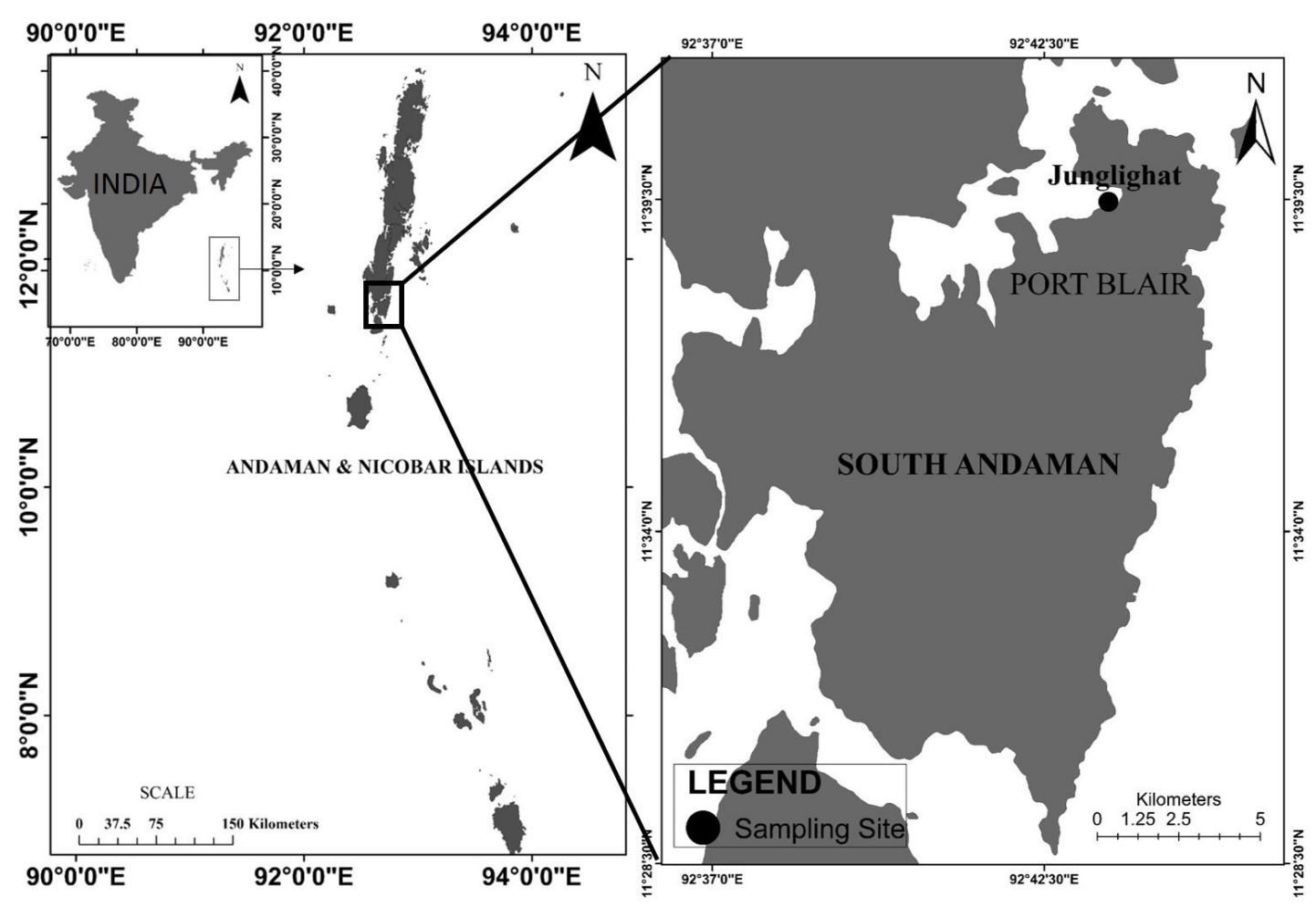

Figure 1. Map shows study area.

this family are of special interest because they are incomplete parasites. They act as either commensals or Micropredators on fishes [12].

An Argathona was mainly consist of 12 species. They are mostly found in tropical and subtropical marine habitats throughout the Indo- west pacific at depth ranging from 8 to $267 \mathrm{~m}$ [11]. One of the widely distributed and economically important marine fish family in Indian waters is the family Serranidae. Circumscribed 137 species presented in this family, out of which 110 species are known in the Indo-Pacific region (Fishbase 2010) and 70 species under 15 genera are present in Indian waters. In this family, Epinephelus is the major genera in world with over 97 species, out of which 77 species are contributing from Indo-Pacific and 38 species from Indian waters [13]. Being an essential part in the coral reef ecosystem, the members of the Serranidae family are mostly living in coral reefs. These fishes have important role in the coral reef communities and there by constitution of rocky bottom. Groupers are being subjected to increasing global fishing pressure for its food, medical purposes, and ornamental display. [14, 15, 16, 17].

Generally parasitic isopods are typically ma- rine and they inhabit the warmer seas [7]. Until now few studies were performed on parasites collected from Indian marine fishes [18, 19, 20, 21]. In India, earlier studies were reported three parasitic isopods under these genus Argathona namely Argathona muraenae from Bombay waters. A. rhinoceros and Argathona normani both from Kerala waters. Recently Chelladuri et al. (2016) reported the Argathona macronema from Gulf of Mannar. The early report from Andaman and Nicobar Islands is only one species, Corallana basalis of Corallinidae family reported in Nicobar [22]. The present report deals with the parasitic isopoda species Aargathona rhinoceros and A. macronema found on the host fish Epinephelus spp. in South Andaman. These two species of isopods were collected from the nostril cavity of the individual host fishes (Epinephelus spp.). There is no earlier record of these isopods from Andaman and Nicobar Islands.

\section{Material and Methods}

The samples of grouper Epinephelus spp. were collected from junglighat fish landing center (Lat.11³9'25.09"N; Long. 9243'30.35"E), South Andaman in April, 2017 (see Figure 1). Parasitic 
isopods were collected from the fish nostrils of Epinephelus spp. using forceps and preserved in $70 \%$ of ethanol. Mouthparts and appendages of isopods were carefully dissected using dissecting needles. Drawings were made using a compound microscope (Olympus BX 41) and stereo microscope (Nikon SMZ 1500). The isopods were identified using identification books [11, 23, 24] with the help of OLYMPUS BX 41 compound microscope. The total length of isopod was measured and recorded in millimeters. Specimens were deposited in zoological survey of India, Port Blair, Andaman and Nicobar Islands, India.

\section{Results and Discussion}

Taxonomic description

Order- Isopoda Latreille 1817

Family- Corallanidae Hansen 1890

Genus- Argathona Stebbing 1905

Species- A. rhinocerous Bleeker 1857

A. macronema Bleeker 1857

\section{Argathona rhinocerous (Bleeker 1857) Description}

Body size $-35 \mathrm{~mm}$, body is long. The dorsal surface of the body is smooth and whitish brown in color (see Figure 2). Anterior margin of cephalon is with small rostral projection, narrower at apex than at base; dorsal surface of cephalon is depressed behind rostrum, ridge running from rostra process to inside of the eye, anterior margin with carina extending posterior, bisecting the eye.

Pereonites 1-7, sub-equal in length, first pereonite is small than the remaining pereonites; coxae large, those of pereonites $4-7$ with very conspicuous carinae. Paired penes present on sternite 7 .

Antennule (see Figure 3a) having three peduncle articles, second article is slightly shorter than first article, and peduncle article 3 is slightly shorter than second article. Flagellum consist of 15 articles, the first two are sub-equal in length and longer than remainder, and extending to posterior of eye.

Antenna (see Figure 3b) having five peduncle articles. Peduncle articles 1 and 2 are sub-equal in length and shorter than article 3, peduncle article 4 is slightly shorter than 5 , flagellum consist of 36 articles and extending to middle of pereonite 3 .

Frontal lamina (see Figure 3c) is pentagonal, it is slightly longer than broad. Maxilla (see Figure 3d) with single spiniform process at base of termi-

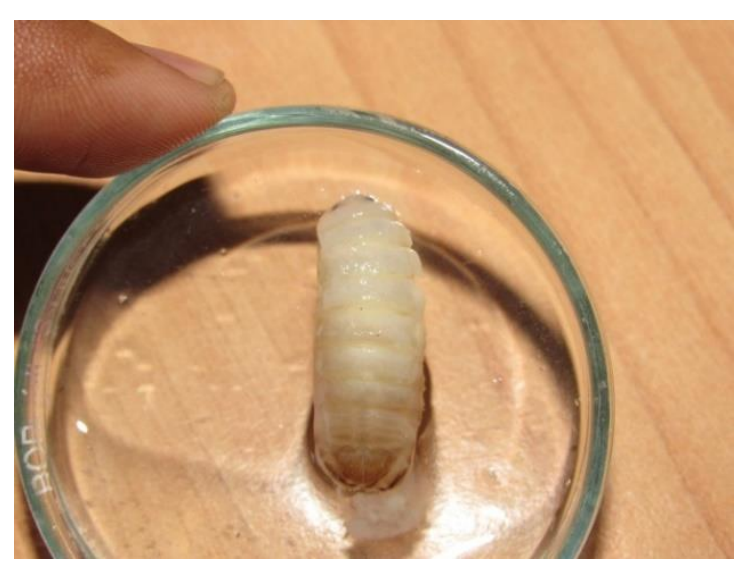

Figure 2. A. rhinocerous from the fish nostrils of Epinephelus spp.

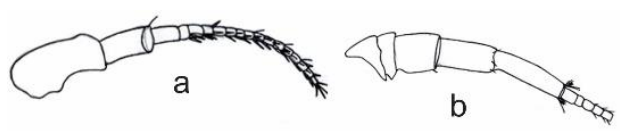

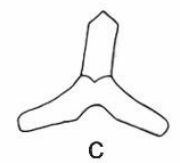

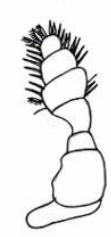

e

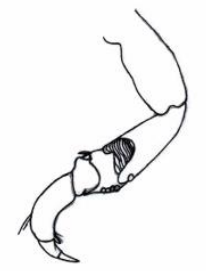

$f$

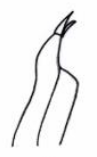

d

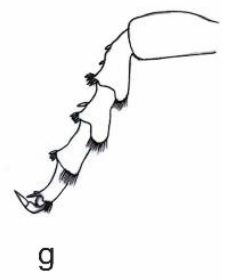

Figure 3. A. rhinocerous: antennules (a), antenna (b), frontal lamina (c), maxillia (d), maxilliped (e), pereopod 1 (f), and pereopod 7 (g)
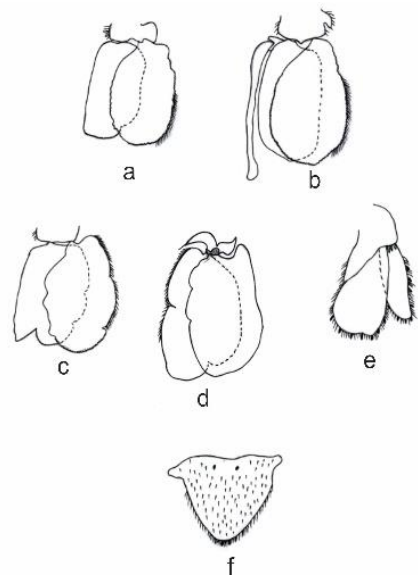

Figure 4. A. rhinocerous: pleopod 1 (a), pleopod 2 (b), pleopod 3 (c), pleopod 5 (d), uropods (e), and pleotelson (f) 
nal unguis. Maxilliped (see Figure 3e) with palp articles 2 and 3 are partially coalesced, but with visible suture.

First Pereopod (see Figure 3f) with few setae, ischium with round yellow colour, tubercle-like spine at inferior distal angle, merus with 4 large stout backwardly directed spines on inferior margin, single spine present at inferior distal angle.

Pereopod 7 (see Figure 3g) with stout spines at inferior distal angles of ischium, merus and carpus, superior distal angles with more slender spines.

Pleopods (see Figure 4a-d) with peduncle broader than long. Rami of first and second are setigerous, pleopod 3 with exopodsetigerous, pleopods 4 and 5 with both rami is non-setigerous. Appendix masculina is not extending beyond inner ramus of endopod, apex with small round projection.

Uropods with peduncle armed with 3 spines on ventral lateral angle. Uropods (see Figure 4e) with both rami broadly rounded, fringed with marginal setae and spines, exopod shorter and narrower than endopod which extends a little beyond apex of telson. Pleotelson (see Figure 4f) broadly rounded, lateral margins slightly sinuate, dorsal surface with numerous setae, margins with dense ringe of setae among which stout spines are present.

\section{Argathona macronema (Bleeker, 1857) Description}

Body size $-5 \mathrm{~mm}$, shape of the body is sub-oval and width is moderate. Dorsal surface of the body is distinctly punctuated and with short setae near lateral and posterior margins of the peraeons (see Figure 5). Cephalon is wider then compare to the medial length, anterior margin of cephalon is rounded, faintly conical, through a little median. Eyes are large.

Peraeon segment one implementation base of cephalon. First, third and fourth segments are subequal in length, longer than second peraeon segment. Fifth and sixth segments are also sub-equal in length, seventh segment is little shorter then sixth peraeon segment. Coxal plates are clearly visible in dorsal view, the coxal plates of second and third peraeon segments roundely sub rectangular, not extending past level of posterior margins of segments, reaming plates are sub-acute posteriorly, reaching beyond hinder margions of their segments.

Antennule (see Figure 6a) reach to beyond the end of fourth peduncle article of second antennae, flagellum consist of fourteen articles, the first article being very short and second one is longer than remainder, with terminal stylet.

Antenna (see Figure 6b) having five peduncle articles, with long flagellum which reaching beyond level of apice of coxal plate of sixth peraeon segment. Flagellum consist of forty-three articles.

Frontal lamina (see Figure 6c) is little elongate, twice as long as width, anteriorly a little dilated and with anterior margin sub angularely rounded. A strong claw is terminated in an Outer lobe of first maxilla (see Figure 6d) a small hooked spine is having the inner side of the base; inner lobe is apically sub truncate. Maxillipeds is a five jointed palp (see Figure 6e) the partition between second and third article is slightly combining of the five jointed palps.

Pereopods (see Figure 6f-g) fairly stout, bi-ungulate dactyli, inside claw is small. Pereopod one merus having six short, stout spines on inner margin and three slender spines are present outer distal angels; two small spines are present on inner edge of carpus. Seventh pereopod ischium, merus and carpus are sub-equal in length.

All pleopods (see Figure 7a-c) are setigerous, but endopod of fifth pleopod is non setigerous; appendix masculina is arising from endopod region pleopod 2, the terminal region has small acute projection.

First pleon segment is short concealed beneath the last peraeon segment, fifth longer than second, third and fourth segments; pleon segments are subequal in length, postero-lateral angles of first three segments sub-acute, those of fourth concavely truncate, fifth segment narrower than fourth segment and fifth segments have round posterolatreal angles not wholly covered by fourth segment.

Uropods (see Figure 7d) extending beyond level of apex of pleon, inner process of pleopod reaching to middle of endopod, the endopod is broader than exopod, which is rounded posteriorly, and is about same length but twice as wide as exopod; margins of both branches are sinuate and furnished with hairs, intermixed with short spines.

Telsonic (see Figure 7e) segment is more than one - third wider than medial length, with lateral margins sinuate converging to the sub-acutely 


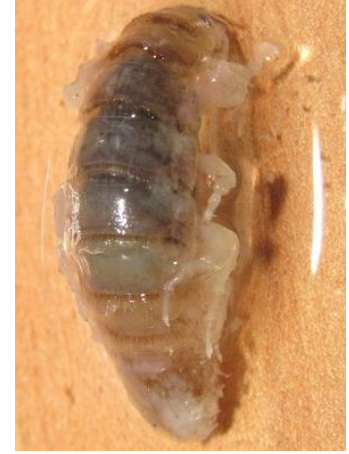

Figure 5. A. macronema from the fish nostrils of Epinephelus spp.
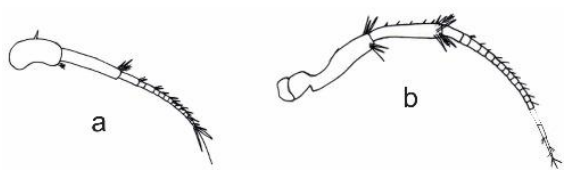

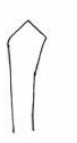

C
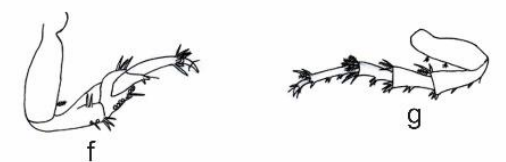

Figure 6. A. macronema: antennules (a), antenna (b), frontal lamina (c), maxillia (d), maxilliped (e), pereopod 1 (f), and pereopod 7 (g)
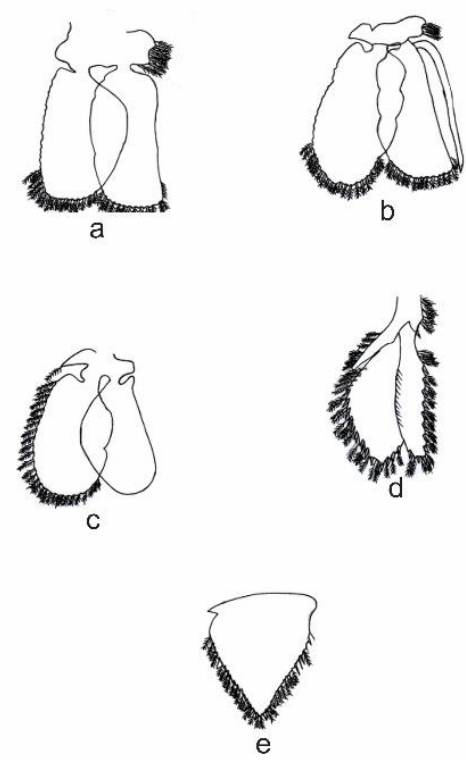

Figure 4. A. macronema: pleopod 1 (a), pleopod 2 (b), pleopod 3 (c), pleopod 5 (d), uropods (e), and pleotelson (f) rounded apex, dorsal surface has short stout hair present. Posterior half of lateral margins furnished with hairs and apex of which with six short stout spines.

In the present study Argathona sp. found in the nostril cavity of Epinephelus spp. (Epinephelus coioides and Epinephelus tauvina). Out of 24 specimens of $E$. coioides, the isopod parasite $A$. rhinocerous have been recorded in 4 specimens. These parasitic isopod pleopods have lost most of their marginal setae and maxilliped showed clearly the partial fusion of palp articles 2 and 3, a similar position was figured by Bruce (1982). One isopoda parasite $A$. macronema have been recorded out of 5 specimens of Epinephelus tauvina. This specimen is closely resembling to the specimen described by Richardson (1910). It occurs commonly in the nasal passages of Serranids. Chelladurai et al. (2016) recently reported A. macronema in Gulf of Mannar region from the host of Epinephelus malabaricus and Lutjanus rivulatus. From earlier studies it was clear that the genus Argathona was scantly presented in India, and many studies have been reported from Australian waters [9]. Till now there is no records regarding this genus in Andaman Islands. In Thailand coast under this genus only one species A. rhinocerous is reported and in Indonesia regarding these genus 3 species are reported $A$. macronema, $A$. rhinocerous, A. stebbing and Srilankan coast only two species are reported $A$. rhinocerous, A. normani. Now these genus range is extended from Andaman Islands. The genus Argathona and Tachaea have high percentage of species (50 and $84 \%$ respectively) recorded as temporary parasites. It is commonly found in association with serranids, carangids and other commercially important fishes. These isopod parasites (A. rhinocerous and A. macronema) were previously reported from Epinephalus chlorostigma, E. malabaricus, Tetrodon leopardus, Variolalouti, Plectropoma leopardus, E. tauvina, Diagramma cinerascens, Psedolabrassps, Trachichtodes affinis, and Cromileptes altivelis [11].

Fish parasites are critical part of our aquatic ecosystem and they are frequent in both natural as well as cultured populations of fish [7]. In aquaculture, with significant economic consequences, this parasite can also heavily infect a large proportion of fish and able to reproduce rapidly which may lead to further loss [25]. These parasitic forms 
not only accommodate in the commercially important fishes, it is also showing to the impact a variety of commercially important hosts, including false king crabs, brachyuran crabs, king crabs and shrimp. [26, 8, 27, 28].

Parasitic isopods have been analysed for use in a variety of practical frameworks. Some parasitic isopods have been even examined as a potential biological control for some introduced host decapods [29 - 33]. Parasitic isopods also have been used as biological indicators of disturbed habitats which may make hosts more vulnerable to various environmental toxins [34, 35]. Around the world dried isopods are used as folk medicines [8].

A few related works are available on the isopod fish parasites and its nature of parasitism. Unfortunately, both fish parasitologists and the isopoda specialist conducted little more basic taxonomic studies by disregarding their biology [2] This study revealed the first occurrence of parasitic isopods (A. rhinoceros and A. macronema) from two Epinephelus species in the South Andaman.

Andaman and Nicobar Islands are rich in fish population [36], however the studies on parasitic isopods are very scanty. The present study documented parasitic isopods to have an idea about them from the economically valued fishes. This study may help the researchers to enhance thus knowledge on parasitic isopod and to increase the fish population that are free from the parasites by controlling them.

\section{Conclusion}

Parasitic isopoda work in commercially important fishes are very scanty and no such studies have been made in Andaman\& Nicobar Islands. Though, fishes are commercially important component in the food web and they play an important ecological role to maintain a balanced ecosystem. Present attempt was a preliminary work on this parasitic isopod and it's needed a proper survey to understand the biology and its life cycle of targeted host fishes, which is an economically important fish in Andaman and Nicobar Island.

\section{Acknowledgment}

The authors are thankful to the Pondicherry University for providing the necessary fund and lab facilities to carry out this present study. I am also grateful to Dr. Niel L. Bruce, Museum of
Tropical Queensland, Queensland Museum, Townsville, Australia for helping me by providing the valuable identification.

\section{References}

1. Ravichandran S, Rameshkumar G, Kumaravel K (2009) Variation in the morphological features of isopod fish parasites. World Journal of Fish and Marine Sciences 1 (2): 137 - 140.

2. Ravichandran S, Rameshkumar G, Mahesh Babu B, Kumaravel K (2009) Infestation of Rastrelliger kanagurta, with Cymothoid Isopod, Joryma brachysoma in the Colachel Environment of Southwest Coast of India. World Journal of Fish and Marine Sciences 1 (2): 80 - 84.

3. Anand Kumar A, Rameshkumar G, Ravichandran $S$ et al. (2016) Distribution of isopod parasites in commercially important marine fishes of the Miri coast, East Malaysia. Journal of Parasitic Diseases 41 (1): 55 - 61. doi: 10.1007/s12639-016-0749-6.

4. Vijayakumar P, Veerappan N (2012) Endohelminth parasites of two scianidae fishes from the south- east coast of India. International Journal of Environmental Biology 2 (3): 183 - 186.

5. Ravichandran S, Ajith Kumar TT, Ronold Ross P, Muthulingam M (2007) Histopathology of the infestation of parasitic Isopod Joryma tartoor of the host fish Parastromateus niger. Research Journal of Parasitology 2 (1): 68 - 71. doi: 10.3923/jp.2007.68.71.

6. Rameshkumar G, Ravichandran S (2014) Problems caused by isopod parasites in commercial fishes. Journal of Parasitic Diseases 38 (1): 138 - 141. doi: 10.1007/s12639-012-0210-4.

7. Chelladurai G, Balakrishanan S, Rameshkumar G, Banumathi K (2015) New occurrence of parasitic isopod Argathona sp. (Stebbing, 1905) from Epinephelus undulosus in the Tuticorin coast, Gulf of Mannar region. Journal of Parasitic Diseases 40 (4): 1365 - 1368. doi: 10.1007/s12639-015-0691$\mathrm{z}$.

8. Bunkley-Williams L, Williams EH Jr, Bashirullah AKM (2006) Isopods (Isopoda: Aegidae, Cymothoidae, Gnathiidae) associated with Venezuelan marine fishes (Elasmobranchii, Actinopterygii). Revista de Biología Tropical International Journal of Tropical Biology and Conservation 54 (3): $175-188$.

9. Chelladurai G, Mohanraj J, Jayanthi GR (2016) First occurrence of Argathona macronema (Bleeker, 1857) (Isopoda, Cirolanidae) on coral 
reef fishes along the Tuticorin coastal water, Gulf of Mannar. Journal of Parasitic Diseases 41 (1): 206 - 210. doi: 10.1007/s12639-016-0779-0.

10. Praveenraj J, Saravanan K, Puneeth Kumar P et al. (2016) First record on the occurrence of Ryukyua circularis (Pillai, 1954) a parasitic cymothoid (Crustacean, Isopoda) infesting the clupeid fish Amblygaster sirm (Walbaum) from Andaman Islands, India. Journal of Parasitic Diseases 41 (2): 593 - 595. doi: 10.1007/s12639-0823-0.

11. Delaney PM (1989) Phylogeny and biogeography of the marine isopod family Corallanidae (Crustacea, Isopoda, Flabellifera). Contribution in Science. Los Angeles, Natural History Museum of Los Angeles County.

12. Smit NJ, Bruce NL, Hadfield KA (2014) Global diversity of fish parasitic isopod crustaceans of the family Cymothoidae. International Journal for Parasitology: Parasites and Wildlife 3 (2): 188 - 197. doi: 10.1016/j.ijppaw.2014.03.004.

13. Yennawar P, Prasad T, Anil M (2011) Occurrence of three red listed species of Epinephelus (Perciformes, Serranidae) on Digha coast. India. Journal of Threatened Taxa 3 (10): 2150 - 2152. doi: 10.11609/JoTT.o2641.2150-2.

14. Pauly D, Christensen V, Guénette S et al. (2002) Towards sustainability in world fisheries. Nature 418: 689 - 695. doi: 10.1038/nature01017.

15. Vincent ACJ (2006) Live food and non-food fisheries on coral reefs and their potential management. In: Cote IM, Reynolds JD (Eds.) Coral reef conservation. Cambridge, Cambridge University Press. pp $\quad 183 \quad$ - $236 . \quad 2$ doi: 10.1017/CBO9780511804472.008.

16. Aburto-Oropeza O, Erisaman B, Valdez-Ornelasy V, Danemann G (2008) Commercially important serranid fishes from the Gulf of California - Ecology, fisheries and conservation. Ciencia y Conservacion 2008 (1): 1 - 23.

17. Kandula S, Shrikanya KVL, Deepti VAI (2015) Species diversity and some aspects of reproductive biology and life history of groupers (Pisces: Serranidae: Epinephelinae) off the central eastern coast of India. Marine Biology Research 11 (1): 18 - 33. doi: 10.1080/17451000.2014.949271.

18. Bruce NL (2003) New genera and species of sphaeromatid isopod crustaceans from Australian marine coastal waters. Memoirs of Museum Victoria 60 (2): $309-370$. doi: 10.24199/j.mmv.2003.60.28.

19. Ravichandran S, Ajithkumar TT (2008) Secondary microbial infestation in Ilisha melastoma due to isopod fish parasite. Journal of Fisheries and Aquatic Science 3 (1): 92 - 96. doi: 10.3923/jfas.2008.92.96.

20. Trilles JP, Ravichandran S, Rameshkumar G (2011) A checklist of the Cymothoidae (Crustacea, Isopoda) recorded from Indian fishes. Acta Parasitologica 56 (4): 445 - 459.doi: 10.2478/s11686011-0077-z.

21. Rameshkumar G, Ravichandran S, Sivasubramanian K, Trilles JP (2013) New occurrence of parasitic isopods from Indian fishes. Journal of Parasitic Diseases 37 (1): 42 - 46. doi: 10.1007/s12639-012-0128-x.

22. Heller C (1868) Crustaceen, ordo Isopoda. In: von Scherzer KR (Eds.) Reise der Österreichischen Fregatte Novara um die Erde in den Jahren 1857, 1858, 1859 unter den Befehlen des Commodore B. von Wüllerstorf- Urbair. Wien, C. Gerold's Sohn. pp $130-147$.

23. Bruce NL (1982) Species of Argathona Stebbing, 1905 (Isopoda, Corallanidae) new to Australia, with description of two new species. Crustaceana 42 (1): 12 - 25.doi: 0.1163/156854082X00650.

24. Richardson H (1910) Marine Isopods collected in the Philippines by U.S. Fisheries Steamer Albatross in 1907-1908. Department of Commerce and Labor. Washington, Government Printing Office. pp $1-44$.

25. Rameshkumar G, Ravichandran S, Sivasubramanian K (2014) A new record of parasitic isopod for the Indian fauna (Mothocya karobran Bruce, 1986) from Strongylura strongylura in the Pazhayar region, Southeast coast of India. Journal of Parasitic Diseases 38 (3): 328 - 330. doi: 10.1007/s12639013-0268-7.

26. Lovrich GA, Roccatagliata D, Peresan L (2004) Hyperparasitism of the cryptoniscid isopod Liriopsis pygmaea on the lithodid Paralomis granulata from the Beagle Channel, Argentina. Diseases of Aquatic Organisms 58 (1): 71 - 77. doi:10.3354/dao058071.

27. Rajkumar M, Manokaran S, Sun J, Trilles J (2011) A review of Epipenaeon ingens Nobili, 1906 (Isopoda: Bopyridae) host species and documentation of a new host, Metapenaeopsis stridulans (Alcock, 1905) (Decapoda: Penaeidae). Chinese Journal of Oceanology and Limnology 29 (1): 136 - 140. doi: 10.1007/s00343-011-9923-y.

28. Vinuesa JH, Balzi P (2010) Infestation of Lithodes santolla (Decapoda: Lithodidae) by Pseudione tu- 
berculata (Isopoda: Bopyridae) in San Jorge Gulf, Southwestern Atlantic Ocean. Marine Biology Research 6 (6): 608 - 612. doi: 10.1080/17451000903478327.

29. Kuris AM, Lafferty KD, Torchin ME (2005) Biological control of the European green crab, Carcinus maenas: Natural enemy evaluation and analysis of host specificity. In: Hoddle MS (Eds.) Second international symposium on biological control of Arthropods. Riverside, University of California. pp $102-115$.

30. Itani G (2004) Host specialization in symbiotic animals associated with thalassinidean shrimps in Japan. In Proceedings of the symposium on Ecology of large bioturbators in tidal flats and shallow sublittoral sediments- from individual behavior to their role as ecosystem engineers. Edited by Tamaki A. Nagasaki, Nagasaki University Press. pp 33-43.

31. Williams JD, An J (2009) The cryptogenic parasitic isopod Orthione griffenis Markham, 2004 from the eastern and western Pacific. Integrative and Comparative Biology 49 (2): 114 - 126. doi: 10.1093/icb/icp021.

32. Chapman JW, Dumbauld BR, Itani G, Markham JC (2011) An introduced Asian parasite threatens Northeastern Pacific estuarine ecosystems. Biological Invasions 14 (6): 1221 - 1236. doi: 10.1007/s10530-011-0151-3.
33. Dumbauld BR, Feldman K, Armstrong D (2004) A comparison of the ecology and effects of two thalassinidean shrimps on oyster aquaculture operations in the eastern North Pacific. In Proceedings of the symposium on Ecology of large bioturbators in tidal flats and shallow sublittoral sedimentsfrom individual behavior to their role as ecosystem engineers. Edited by Tamaki A. Nagasaki, Nagasaki University Press. pp $53-61$.

34. Penha-Lopes G, Torres P, Cannicci S et al. (2011) Monitoring anthropogenic sewage pollution on mangrove creeks in southern Mozambique: A test of Palaemon concinnus Dana, 1852 (Palaemonidae) as a biological indicator. Environmental Pollution 159 (2): 636 - 645. doi: 10.1016/j.envpol.2010.09.029.

35. Williamson CJ, Pennington PL, Curran MC (2009) Toxicity of synthetic pyrethroid insecticides to the grass shrimp, Palaemonetes pugio, parasitized with the bopyrid isopod, Probopyrus pandalicola. Journal of Environmental Science and Health 44 (8): 810 - 816. doi: 10.1080/03601230903238426.

36. Dam Roy S, George G (2010) Marine resources of islands: Status and approaches for sustainable exploitation/ conservation with special emphasis to Andaman and Nicobar. The Indian Journal of Animal Sciences 80 (4): 57 - 62 . 